\title{
Epigenetics and Gene Silencing in Transgenic Plants
}

\author{
Aniket Malage and Sibi G* \\ Head of the Department, Department of Biotechnology, Indian Academy Degree College-Autonomous, \\ Bengaluru, India
}

*Corresponding Author: Aniket Malage and Sibi G, Head of the Department, Department of Biotechnology, Indian Academy Degree College-Autonomous, Bengaluru, India

\begin{abstract}
The introduction of transgenes in genetically modified plants can be silenced and also cause the silencing of endogenous plant genes. In this mechanism, silencing can occur transcriptional level and post transcriptional level but in case of silencing the endogenous genes seems predominantly posttranscriptionally. A major factor of this research to dissect the process of these sequence homology dependent gene silencing phenomena and different factors plays a role such as DNA methylation, transgene copy number as well as gene expression factors and possible modification of RNAs. Undesired transgene silencing is one of major concern in transgene technology used in crop improvements and this review gives the relationship between these factors and the bridge between transcriptional and post transcriptional gene silencing and discuss various observation correlated with silencing of gene.
\end{abstract}

Keywords: Epigenetics, gene silencing, transgenic plants, transgene.

\section{INTRODUCTION}

Gene silencing is defined as regulation of expression gene in a cell to prevent the exposed of a particular gene. Transgenes don't always same as expected and changing in the expression of transgenes in individual that is not because of difference in copy number. Nowadays, silencing of gene has been a confounding area of research and development course and the mechanism of gene silencing is not yet fully understood. In gene silencing process, a lot of mutations chemistry has been shown in various plant species like Para mutation. Recently the mechanism has become so much apparent that associated with the transgene-mediated silencing.

Epigenetic gene silencing is also a biological phenomenon in which the gene expression is mediated by DNA modification and RNA modification and its main mechanism is responsible for the defending the host genomes contrary to jumping genes elements and duplicated gene members as a silencer of transgenes. The epigenetic gene silencing mechanism is highly complex and not fully known yet. Transcription and post-transcriptional gene silencing mechanism mainly defined the degradation of cytosolic mRNA of endogenous genes. For plant expressing a transgene stability and segregation is main required factor (Shrawat et al., 2007; Weinhold et al., 2013).

\section{GeNE SilenCing AND EPIGENETICS}

The main important factor associated with silencing of gene is based on number of transgene per integration site and transmission of T-DNA may enter two or more T-DNAs at the common chromosomal site (Prols and Meyer, 1992). The two main ways of gene silencing 1) transcriptional gene silencing that analyse from promoter inactivation and 2) post - transcriptional gene silencing in which promoter is active but mRNA can't accumulate. And mainly epigenetics deals with the correlation of genes and their results which gives the phenotype of a syatem (Waddington, 1942). In study of epigenetics, there are two main classes of transgene silencing in which first position effects related to expression of a foreign gene that is negatively regulated by flanking host DNA (Matzke et al., 2000). And the second main type of transgene silencing phenomena is related to epigenetic regulation and inactivation mechanism that can uptake multiple copies of same or homologous sequence inserted in a genome and it is also known as homology dependent gene silencing (Meyer and Saedler, 1996). 


\section{TransCriptional LEVEl GENE SilenCING}

Transcriptional level gene silencing states methylated patterns and transgenes are easily methylated to cytosine residue that is locus within $\mathrm{CG}$ and CNN sequences. For specific transgene, DNA methylation should be sequence specific (Matzke et al., 2007). At both transcriptional and post transcriptional levels, methylation in promoter regions, histones or any coding regions under influence the expressions of genes (Huettel et al., 2006) (Regulski et al., 2013; Tsuchiya and Eulgem, 2013). And another proper fact about transcriptional gene silencing in transgenic plants is correlated DNA methylation with structural changes and showing an increased level of chromatin condensation (Van Blokland et al., 1997). The transgenes response to environmental change was confirmed at transcriptional gene silencng (Meyer et al., 1992; Meyer, 2015).

According to transcriptional cis inactivation in plants, the transgenes penetrates into genome at random places by copy number, penetration site as well as local arrangements in every transformation process. It is stated that cis transcriptional gene silencing occurs as an outcome of combination between closely related species of transgenes that leads to the formation of secondary DNA structures which are the main sites for DNA methylation (Vaucheret and Fagard, 2001). 35 S promoter at the $\mathrm{CpG}$ and $\mathrm{CpNpG}$ sites of transgene for cytosine methylation were also showed in transgene grapevine transformed with Grapevine fan leaf virus coat protein gene (Gambino et al., 2010).

In transcriptional trans-inactivation process, the gene silencing process may predict from unidirectional effects of one particular transgene on another transgene. And silenced and methylated gene, when it is crossed with a plant in which the homologous gene in silenced position (Meyer et al., 1993). Vaucheret and Fagard (2001) and Yamasaki et al. (2011) reported that role of different genes indulged ddmj and ddm2 in transcriptional gene silencing in Arabidopsis transgenic lines and also stated asymmetric cytosine methylation is enhancer region of $35 \mathrm{~S}$ promoter in transgenic procedure.

\section{Post- Transcriptional LeVel Gene Silencing}

Under post- transcriptional level gene silencing, transcripts don't accumulate to continuous transcription (Vaucheret et al., 2001). If the genes are homologous, post transcriptional can silence both endogenous genes and transgenes and even endogenous genes can be switched off when a plant species is transformed with another copy of common gene. Transgene induced viral resistance which counteract post transcriptional gene silencing suggested it's a defense answer to check infection caused by virus (Brigneti et al., 1998; Kasschau and Carrington, 1998; Dalmay et al., 2000).

In post transcriptional gene silencing, there are cis and trans-inactivation in which cis inactivation is showed when any foreign genes like beta-Glucuronidase, neomycin etc. were regulate under strong 35S promoter (Dehio and Schell, 1994; Ingelbrecht et al., 1994; Elmayan and Vaucheret, 1996). When a $35 \mathrm{~S}$ promoter used with double enhancer, showed post transcriptional gene silencing (Elmayan and Vaucheret, 1996; English et al., 1996). After some time, it was found that the transcriptional level was not always higher in silenced plants. The different models came for post transcriptional gene silencing were proposed RNA abundance and IRs (Baulcombe, 1996). And in cis inactivation process, DNA-DNA correlation can proceed to methylation process that can go ahead interfere with transcription and ultimately producing aberrant RNA (Wassenegger et al., 1994).

Both transgenes and endogenous genes reported in post transcriptional gene silencing termed as cosuppression (Napoli et al., 1990). Besides the efficacy of co - suppression is delayed due to not expressed of endogenous host genes (Smith et al., 1990; Vaucheret et al., 1997). Although, it can be calculated that co-suppression may not be reminded as the uni-directional silencing effect of transgenes instead of interaction of host genes and transgenes aids aberrant RNA leading to post transcriptional gene silencing.

\section{Methylated Transgenes and Post Transcriptional Gene Silencing}

Methylated transgenes correlated with post transcriptional genes (Hobbs et al., 1990, 1993; Ingelbrecht et al., 1994; Smith et al., 1994; English et al., 1996). In case of sensitive plants, (Smith et al, 1994) reported that the viral transgene of the viral resistant plants was more involved in methylated process. Some examples like PTGSed nptII genes elaborated the positive and negative impact on methylation of the coding region (Ingelbrecht et al. (1994). Another one is PTGSed uidA genes in the tobacco plants were more methylated near the 3' end of the gene which included the poly-adenylation region Hobbs et al. (1990, 1993). English et al, 1996 explained more evidence that seems to be a bridge between DNA methylation and the RNA based mechanism. 


\section{MECHANISM CORRELATED WITH DELETION OF HOMOLOGOUS TRANSCRIPTS}

According to RNA threshold model if the post transcriptional gene silencing induced, the cells those are capable to measure the levels of specific RNAs. And RNA controlled activity doesn't exist in normal cells or modified by the transgenes, may be as a sort of defense mechanism against the maximum harmful effects of these foreign DNAs. The complementary RNAs synthesized by the plant-encoded RNA dependent RNA polymerase in the cytoplasm (Lindbo et al., 1993; Dougherty and Parks, 1995). It is stated that these complementary mRNAs which are destructed by ds-RNA specific RNases. The explanation of the RNA dependent RNA polymerase / cRNA model is that it explains the strong sequence specificity of post transcriptional gene silencing.

\section{Silencing Characteristics in Transgenic Plants}

In plants, mainly micro RNAs are produced from precursor RNA which is necessary for biogenesis of siRNAs and in regulation of gene expression, miRNA is involved by base-pairing with target RNAs leading to their cleavage in plants. An important regulatory role of micro RNAs could be conserved in other plant species too which are under consideration and other important class of small RNAs is siRNAs that are involved in epigenetic modification (Miki and Shimamoto, 2008). The initiation stage of transgene silencing process has been involving in the generation of double stranded RNA and still under debate about important major factors in transgenic perspective. Therefore, against RNA silencing, the transgenes are generally more sensitive than endogenous genes in plants. And most of viral RNA's contain specific sequences for triggering transgene (De Haan et al., 1992; Lindbo et al., 1993; Mueller et al., 1995).

\section{CONCLUSION}

The epigenetic effects as well as silencing mechanism, the role of transgenic technologies have played a major role in achievements and behind various types of gene silencing mechanism involved in siRNA and miRNA. And the various observations correlated with gene silencing independent pathways. The RNA dependent RNA polymerase model gives many predictions related to production of cRNAs and to generate the mutants in that RNA dependent RNA polymerase genes are knocked out by these plants and also induce the post transcriptional gene silencing process.

\section{REFERENCES}

[1] Shrawat, A. K., Becker, D., and Lorz, H. (2007). Agrobacterium tumefaciensmediated genetic transformation of barley (Hordeum vulgare L). Plant Sci. 172, 281-290

[2] Weinhold, A., Kallenbach, M., and Ian Thomas Baldwin, T. I. (2013). Progressive 35S promoter methylation increases rapidly during vegetative development in transgenic Nicotiana attenuata plants. BMC Plant Biol. 13:99

[3] Prols F, Meyer P. 1992. The methylation patterns of chromosomal integration regions influence gene activity of transferred DNA in Petunia hybrida. Plant Journal 2: 465-475.

[4] Waddington, C. H. (1942). The epigenotpye. Endeavour 1, 18-20.

[5] Matzke, M. A., Mette, M. F., and Matzke, A. J. (2000). Transgene silencing by the host genome defense: implications for the evolution of epigenetic control mechanisms in plants and vertebrates. Plant Mol. Biol. $43,401-415$.

[6] Meyer, P., and Saedler, H. (1996). Homology-dependent gene silencing in plants. Ann. Rev. Plant Physiol. Plant Mol. Biol. 47, 23-48.

[7] Matzke, M., Kanno, T., Huettel, B., Daxinger, L., and Matzke, A. J. (2007). Targets of RNA directed DNA methylation. Curr. Opin. Plant Biol. 10, 512-519.

[8] Huettel, B., Kanno, T., Daxinger, L., Aufsatz, W., Matzke, A. J. M., and Matzke, M. (2006). Endogenous targets of RNA-directed DNA methylation and Pol IV in Arabidopsis. EMBO J. 25, 2828-2836.

[9] Regulski, M., Lu, Z., Kendall, J., Donoghue, M. T., Reinders, J., Llaca, V., et al. (2013). The maize methylome influences mRNA splice sites and reveals widespread paramutation-like switches guided by small RNA. Genome Res. 23, 1651-1662.

[10] Van Blokland, R., Ten Lohuis, M., and Meyer, P. (1997). Condensation of chromatin in transcriptional regions of an inactivated plant transgene: evidence for an active role of transcription in gene silencing. Mol. Genet. Genomics 257, 1-13. 
[11] Meyer, P., Linn, F., Heidmann, I., Heiner Meyerz, A. H., Niedenhof, I., and Saedler, H. (1992). Endogenous and environmental factors influence $35 \mathrm{~S}$ promoter methylation of a maize A1 gene construct in transgenic petunia and its colour phenotype. Mol. Gen. Genet. 231, 345-352.

[12] Meyer, P. (2015). Epigenetic variation and environmental change. J. Exp. Bot. 66, 3541-3548.

[13] Vaucheret, H., and Fagard, M. (2001). Transcriptional gene silencing in plants: targets, inducers and regulators. Trends Genet. 17, 29-35.

[14] Gambino, G., Perrone, I., Carra, A., Chitarra, W., Boccacci, P., Torello Marinoni, D., et al. (2010). Transgene silencing in grapevines transformed with GFLV resistance genes: analysis of variable expression of transgene, siRNAs production and cytosine methylation. Transgenic Res. 19, 17-27.

[15] Meyer, P., Heidmann, I., and Niedenhof, I. (1993). Differences in DNA methylation are associated with a paramutation phenomenon in transgenic petunia. Plant J. 4, 89-100

[16] Yamasaki, S., Oda, M., Koizumi, N., Mitsukuri, K., Johkan, M., Nakatsuka, T., et al. (2011). De novo DNA methylation of the $35 \mathrm{~S}$ enhancer revealed by high-resolution methylation analysis of an entire T-DNA segment in transgenic gentian. Plant Biotechnol. 28: 223-230.

[17] Vaucheret, H., Beclin, C., and Fagard, M. (2001). Post-transcriptional gene silencing in plants. J. Cell Sci. 114, 3083-3091.

[18] Brigneti, G., Voinnet, O., Li, W.-X., Ding, S. W., and Baulcombe, D. C. (1998). Viral pathogenicity determinants are suppressors of transgene silencing. EMBO J. 17, 6739-6746.

[19] Kasschau, K. D., and Carrington, J. C. (1998). A counter-defensive strategy of plant viruses: suppression of posttranscriptional gene silencing. Cell 95, 461-470.

[20] Dalmay, T., Hamilton, A., Mueller, E., and Baulcombe, C. D. (2000). Potato virus X amplicons in Arabidopsis mediate genetic and epigenetic gene silencing. Plant Cell 12, 369-380.

[21] Dehio, C., and Schell, J. (1994). Identification of plant genetic loci involved in a post-transcriptional mechanism for meiotically reversible transgene silencing. Proc. Natl. Acad. Sci. U.S.A. 91, 5538-5542.

[22] Ingelbrecht, I., Van Houdt, H., Van Montagu, M., and Depicker, A. (1994). Post-transcriptional silencing of reporter transgenes in tobacco correlates with DNA methylation. Proc. Natl. Acad. Sci. U.S.A. 91, 10502-10506.

[23] Elmayan, T., and Vaucheret, H. (1996). Expression of single copies of a strongly expressed 35S transgene can be silenced post-transcriptionally. Plant J. 9, 787-797.

[24] English, J. J., Mueller, E., and Baulcombe, D. C. (1996). Suppression of virus accumulation in transgenic plants exhibiting silencing of nuclear genes. Plant Cell 8, 179-188.

[25] Baulcombe, D. C. (1996). RNA as a target and an initiator of posttranscriptional gene silencing in transgenic plants. Plant Mol. Biol. 32, 79-88.

[26] Wassenegger, M., Heimes, S., Riedel, L., and Sanger, H. L. (1994). RNA directed de-novo methylation of genomic sequences in plants. Cell 76, 567-576.

[27] Napoli, C., Lemieux, C., and Jorgensen, R. (1990). Introduction of a chimeric chalcone synthase gene into petunia results in reversible co-suppression of homologous gene in trans. Plant Cell 2, 279- [28]

[28] Smith, C. J., Watson, C. F., Morris, P. C., Bird, C. R., Seymour, G. B., Gray, J. E., et al. (1990). Inheritance and effect on ripeing of antisense polygalacturonase genes in transgenic tomatoes. Plant Mol. Biol. 14, 369-379.

[29] Vaucheret, H., Nussaume, L., Palauqui, J. C., Quillere, I., and Elmayan, T. (1997). A transcriptionally active state is required for post-transcriptional silencing (co-suppression) of nitrate reductase host genes and transgenes. Plant Cell 9, 1495-1504.

[30] Hobbs SLA, Kpodar P, Delong CMO. 1990. The effect of T-DNA copy number, position and methylation on reporter gene expression in tobacco transformants. Plant Molecular Biology 15: 851-864.

[31] Hobbs SLA, Warkentin TD, Delong CMO. 1993. Transgene copy number can be positively or negatively associated with transgene expression. Plant Molecular Biology 21: 17-26.

[32] Smith HA, Swaney SL, Parks TD, Wernsman EA, Dougherty WG. 1994. Transgenic plant virus resistance mediated by untranslatable sense RNAs: expression, regulation, and fate of nonessential RNAs. Plant Cell 6: 1441-1453.

[33] Lindbo JA, Silva-Rosales L, Proebsting WM, Dougherty WG. 1993. Induction of a highly specific antiviral state in transgenic plants: implications for regulation of gene expression and virus resistance. Plant Cell 5: 1749-1759.

[34] Dougherty WG, Parks TD. 1995. Transgenes and gene suppression: Telling us something new? Current Opinion in Cell Biology 7: 399-405. 
[35] Miki, D., and Shimamoto, K. (2008). De novo DNA methylation induced by siRNA targeted to endogenous transcribed sequences is genespecific and OsMet1-independent in rice. Plant J. 56, 539-549.

[36] De Haan P, Gielen JJL, Prins M, Wijkamp IG, Van Schepen A, Peters D, Van Grinsven MQJM, Goldbach R. 1992. Characterization of RNA-mediated resistance to Tomato Spotted Wilt Virus in transgenic tobacco plants. Biotechnology 10: 1133-1137.

[37] Mueller E, Gilbert J, Davenport G, Brigneti G, Baulcombe DC. 1995. Homology-dependent resistance: transgenic virus resistance in plants related to homology-dependent gene silencing. Plant Journal 7: 10011013.

Citation: Aniket Malage and Sibi G, "Epigenetics and Gene Silencing in Transgenic Plants" International Journal of Research Studies in Microbiology and Biotechnology (IJRSMB), vol. 5, no. 4, pp. 12-16, 2019. Available: DOI: http://dx.doi.org/ 10.20431/2454-9428.0504003

Copyright: () 2019 Authors. This is an open-access article distributed under the terms of the Creative Commons Attribution License, which permits unrestricted use, distribution, and reproduction in any medium, provided the original author and source are credited. 